\title{
ON THE INACTIVATION OF THROMBIN BY PLASMA PROTEIN
}

\author{
By JOHN D. STEWART AND G. MARGARET ROURKE
}

(From the Surgical Laboratories of the Harvard Medical School at the Massachusetts General Hospital, Boston)

(Received for publication May 1, 1940)

It has been known for many years that an excess of thrombin is formed during the clotting of blood or plasma, that the excess is rapidly inactivated, and that such inactivation is important in maintaining normal fluidity of the blood (1). Considerable attention has been given to the question of what happens to the excess of thrombin, but little conclusive information has been obtained concerning the phenomenon. Quick, in a study of the mode of action of heparin in preventing coagulation, obtained evidence supporting the opinion of early workers that the property of inactivating thrombin resides in the plasma protein, and specifically in the albumin fraction (2). The present report deals with a study of the rate of inactivation of thrombin in vitro by plasma protein and various fractions of plasma protein.

\section{METHODS}

The human and beef plasma samples used in this study were prepared by adding one part of 1.85 per cent $\mathrm{K}_{2} \mathrm{C}_{2} \mathrm{O}_{4}$ solution to seven parts of fresh blood and centrifuging immediately. A potent thrombin solution was prepared from beef plasma by the method of Eagle (3). The thrombin solution was ampuled and preserved in 2 cold-box at $-40^{\circ} \mathrm{C}$. and, except for the experiments of Figures 2 and 6, the same lot was used throughout

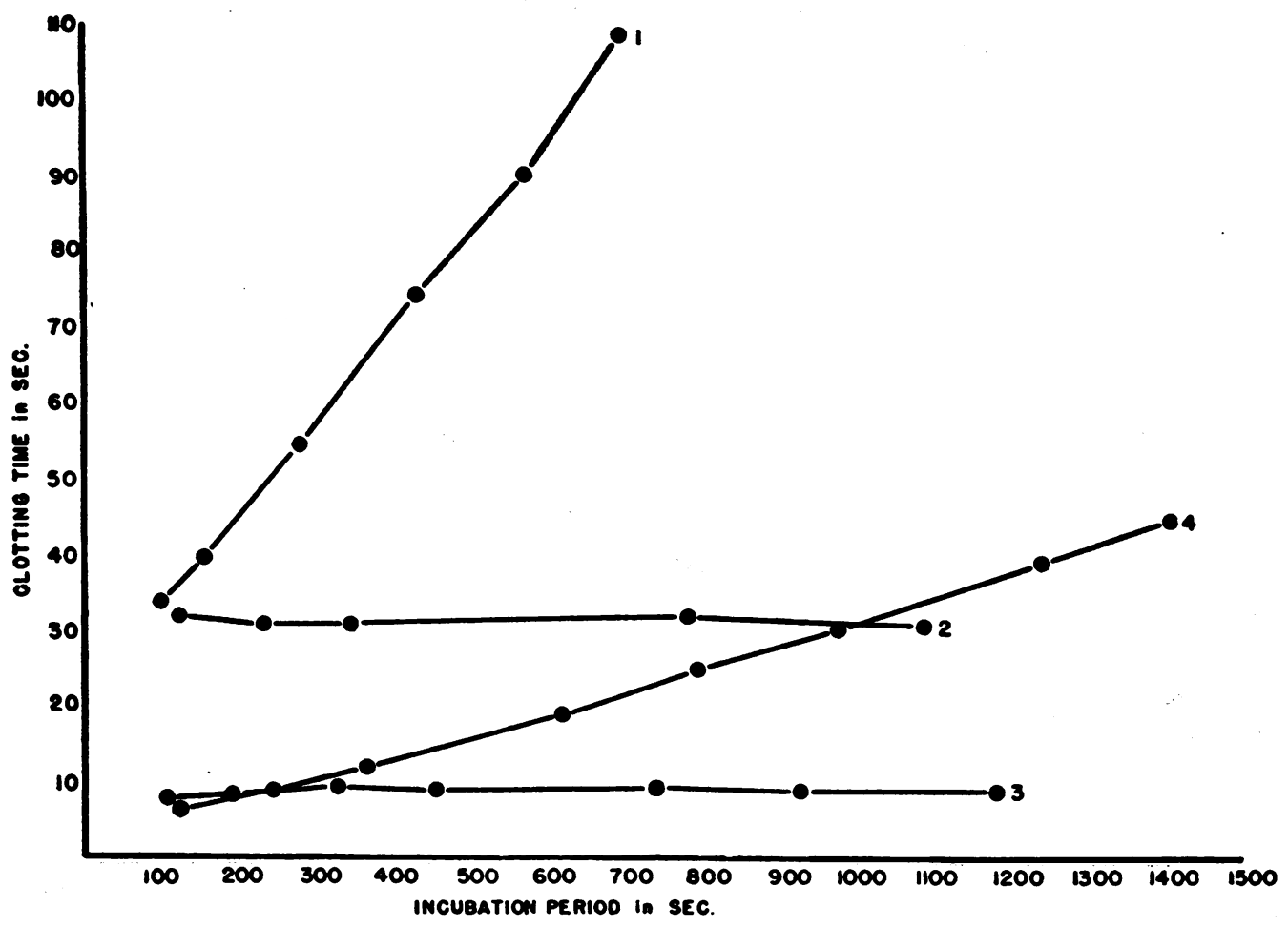

Fig. 1. Thrombin Inactivation Study, Ox Plasma at $37^{\circ} \mathrm{C}$.

Curve $1.2 .0 \mathrm{cc}$. thrombin solution plus $0.2 \mathrm{cc}$. ox plasma incubated, $0.2 \mathrm{cc}$. mixture added to $0.4 \mathrm{cc}$. fibrinogen solution. Curve 2. $2.0 \mathrm{cc}$. thrombin solution plus $0.2 \mathrm{cc}$. fibrinogen solution, $0.2 \mathrm{cc}$. mixture added to $0.4 \mathrm{cc}$. fibrinogen solution. Curve 3 . $2.0 \mathrm{cc}$. thrombin solution plus $0.2 \mathrm{cc}$. fibrinogen solution, $0.2 \mathrm{cc}$. mixture added to $0.4 \mathrm{cc}$. ox plasma. Curve 4 . $2.0 \mathrm{cc}$. thrombin solution plus 0.2 cc. ox plasma, $0.2 \mathrm{cc}$. mixture added to $0.4 \mathrm{cc}$. ox plasma. 
the study. No loss of strength was noted, and $0.1 \mathrm{cc}$. of the thrombin solution clotted $0.5 \mathrm{cc}$. of human plasma in 10 seconds. The total nitrogen content of the thrombin solution was $77 \mathrm{mgm}$. per cent. Fibrinogen solution was prepared from beef plasma by adding one-third volume of saturated $\left(\mathrm{NH}_{4}\right)_{2} \mathrm{SO}_{4}$, centrifuging, dissolving the precipitate in 0.9 per cent $\mathrm{NaCl}$ solution, and subsequent reprecipitation twice. The $\left(\mathrm{NH}_{4}\right)_{2} \mathrm{SO}_{4}$ was removed by dialysis against 0.9 per cent $\mathrm{NaCl}$ solution, and the final volume of the fibrinogen solution was about one-third that of the original plasma. The horse serum and fractions of horse serum protein studied will be described below.

The measurement of the rate of inactivation of thrombin by the protein solution under study was made in every experiment as follows: Two cc. of thrombin solution were placed in a serological test tube in a water bath at $37^{\circ} \mathrm{C}$. and $0.2 \mathrm{cc}$. of the solution being tested was added. The clot which formed when plasma or fibrinogen solution was added was rolled out and it was found to make no difference whether the fibrin pellicle was left in the incubating mixture or not. At various intervals $0.2 \mathrm{cc}$. of the incubating mixture was withdrawn and combined with $0.4 \mathrm{cc}$. fresh human or beef plasma or fibrinogen solution, and the clotting time was measured with a stopwatch. The determination thus consisted of the measurement of the residual thrombin by noting its power to clot a standard substrate. As previously shown (4), a strict linear relationship between thrombin concentration and clotting time under these circumstances does not exist, but for the purposes of the present study this assumption may be made with little error.

\section{PRESENTATION OF DATA}

In the experiments on which Figure 1 is based, the inability of fibrinogen solution to inactivate thrombin is brought out. In curves 2 and 3 fibrinogen solution was added to thrombin and immediate clotting resulted. Nevertheless no inactivation followed. In curves 1 and 4, by contrast, the inactivating power of plasma is well shown. In the test for residual thrombin the fibrinogen solution clots uniformly more slowly than does fresh plasma.

Figure 2 shows composite inactivation curves obtained in a study of human plasma from two individuals over a period of several weeks. In Figure 3 is shown a composite of 16 inactivation curves made by studying plasma samples from the same individual over a period of several weeks.

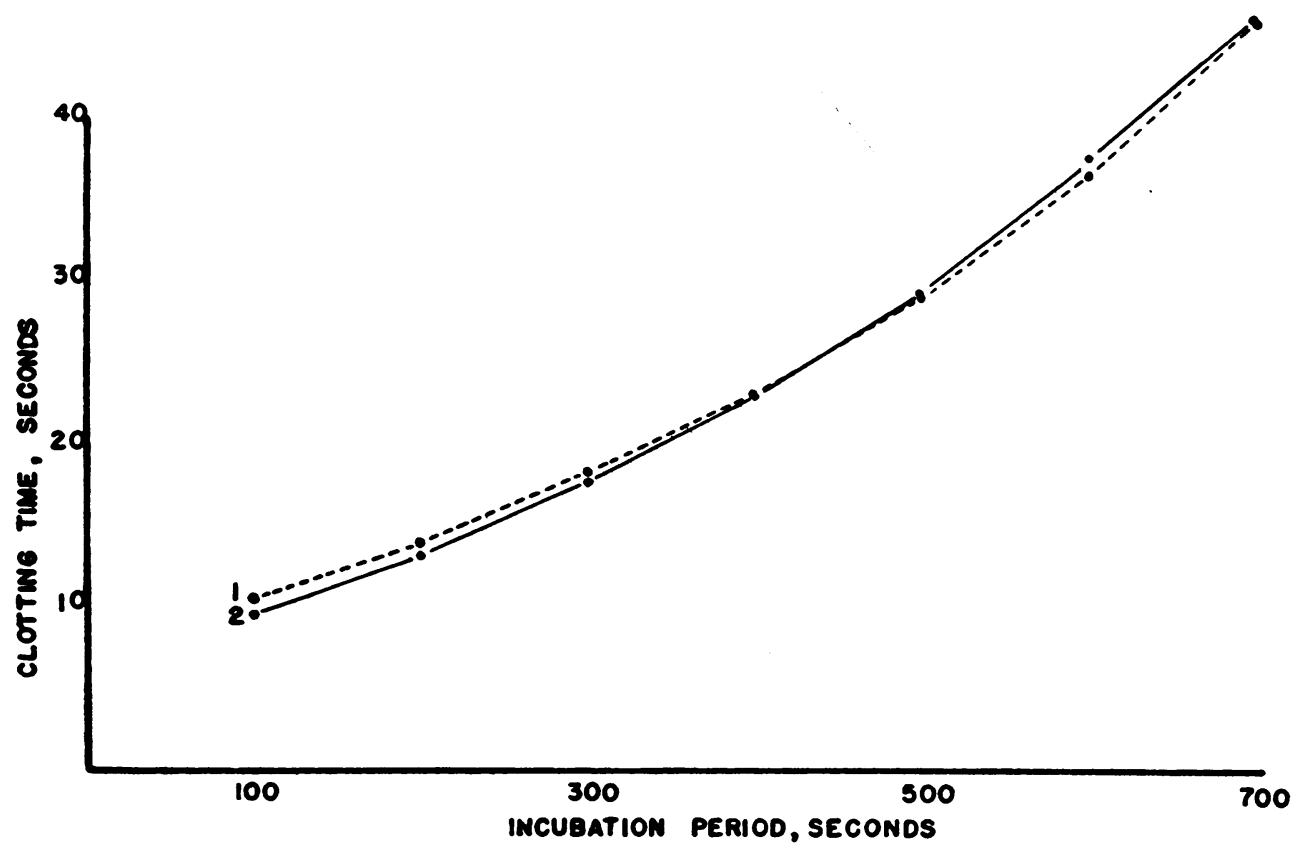

Fig. 2. Thrombin Inactivation Study, at $37^{\circ} \mathrm{C}$., Composite Curves

1. J.D.S., control, 12 curves. 2. G.M.R., control, 12 curves.

Curve 1. $2.0 \mathrm{cc}$. thrombin solution plus $0.2 \mathrm{cc}$. fresh human plasma incubated, $0.2 \mathrm{cc}$. mixture added to $0.4 \mathrm{cc}$. fresh human plasma. Composite of 12 such curves. Curve 2. Similarly made from second control. 


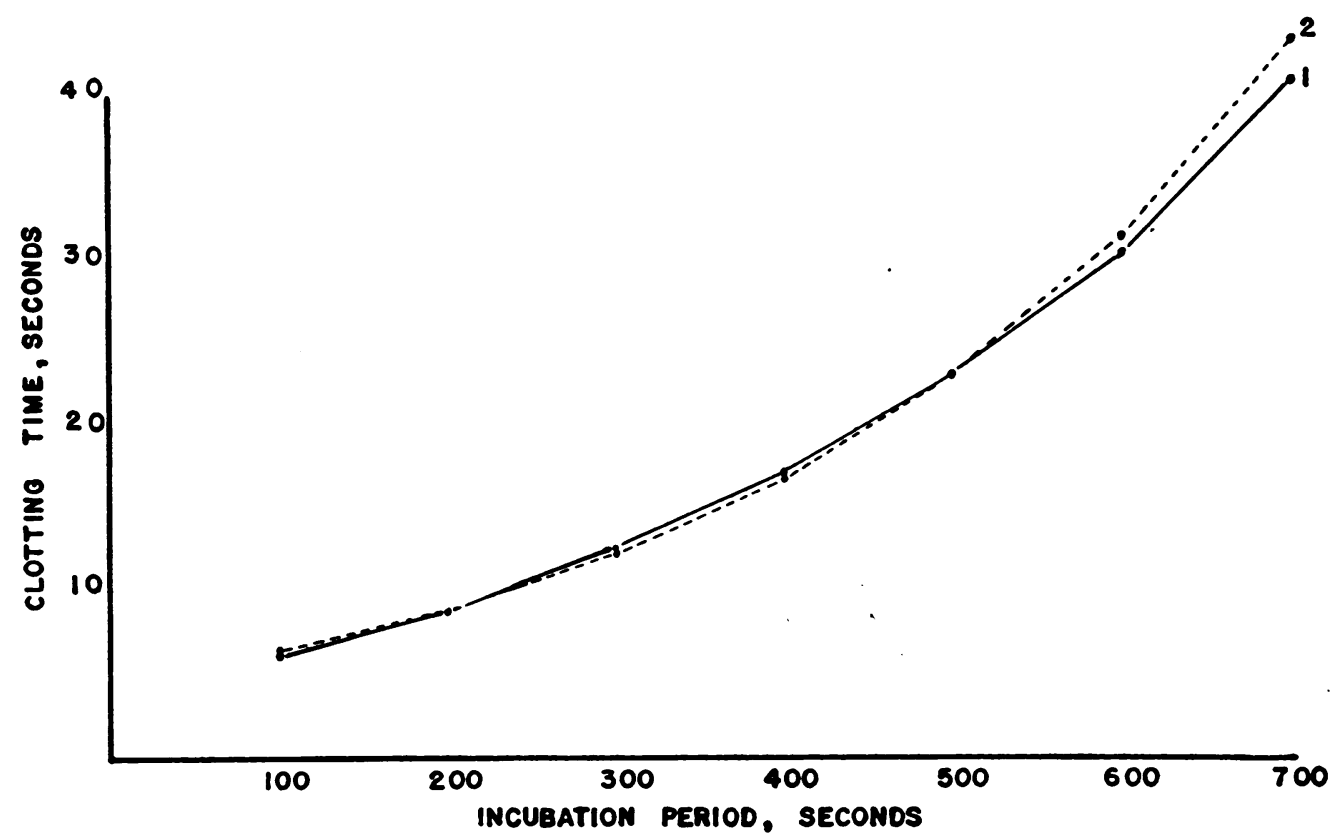

Fig. 3. Thrombin Inactivation Study, at $37^{\circ} \mathrm{C}$.

1. J.D.S., control, composite 16 curves. 2. Theoretical curve $y=(4.59)$ (1.003)

Curve 1. $2.0 \mathrm{cc}$. thrombin solution plus $0.2 \mathrm{cc}$. fresh human plasma, incubated, $0.2 \mathrm{cc}$. mixture added to $0.4 \mathrm{cc}$. fresh human plasma. Composite of 16 such curves. Curve 2. Derived theoretical curve.

Shown also as curve 2 is the theoretical exponential curve derived from two values on the composite curve. In Figure 4 is shown the effect of dialysis and heat on the thrombin inactivating power of human plasma. The plasma tested in curve 2 was dialyzed for 3 hours at $4^{\circ} \mathrm{C}$. against repeated changes of 0.9 per cent $\mathrm{NaCl}$ solution. The slight reduction in inactivating power compared with the undialyzed plasma may be explained by the small increase in volume during dialysis, for which no correction was made. Plasma heated to $60^{\circ} \mathrm{C}$. for 20 minutes under-

TABLE I

Horse serum protein fractions used in experiments shown in Figure 5. Dissoloed in 0.9 per cent $\mathrm{NaCl}$ solution

\begin{tabular}{ccc}
\hline \hline Curve & $\begin{array}{c}\text { Protein } \\
\text { fraction } \\
\left(\mathrm{NH}_{4}\right)_{2} \text { SO, M. }\end{array}$ & $\begin{array}{c}\text { Protein } \\
\text { concentrations }\end{array}$ \\
\hline & & gram per cc. \\
1 & 1.370 & 0.0765 \\
2 & 1.638 & 0.0793 \\
3 & 2.080 & 0.0891 \\
4 & 2.60 & 0.0815 \\
5 & 2.80 & 0.0613 \\
6 & Soluble at 2.80 & 0.0570 \\
\hline
\end{tabular}

went great reduction in inactivating power, while plasma heated to $66^{\circ} \mathrm{C}$. for 20 minutes completely lost this property.

Figure 5 and Table I show data obtained in a study of thrombin inactivating power of horse serum and protein fractions of horse serum, both of which were kindly supplied by Drs. E. J. Cohn and T. L. McMeekin of the Department of Physical Chemistry at Harvard Medical School. The protein fractions were prepared by precipitation from horse serum with varying concentrations of $\left(\mathrm{NH}_{4}\right)_{2} \mathrm{SO}_{4}$, as shown in Table I. After filtration the precipitates were taken up in 0.9 per cent $\mathrm{NaCl}$ solution and freed of $\left(\mathrm{NH}_{4}\right)_{2} \mathrm{SO}_{4}$ by dialysis. The final protein concentrations of the fractions tested are shown in grams per cc., and the values are similar to those of serum. Protein fractions 1 and 2 have no inactivating power, while fractions 3 and 4 exhibit the property to an increasing degree. Fraction 5 precipitated at 2.80 M. $\left(\mathrm{NH}_{4}\right)_{2} \mathrm{SO}_{4}$ is by far the most active fraction tested against thrombin. Fraction 6, however, soluble at $2.80 \mathrm{M}$. $\left(\mathrm{NH}_{4}\right)_{2} \mathrm{SO}_{4}$ and precipitated at saturation has no inactivating power. The meas- 


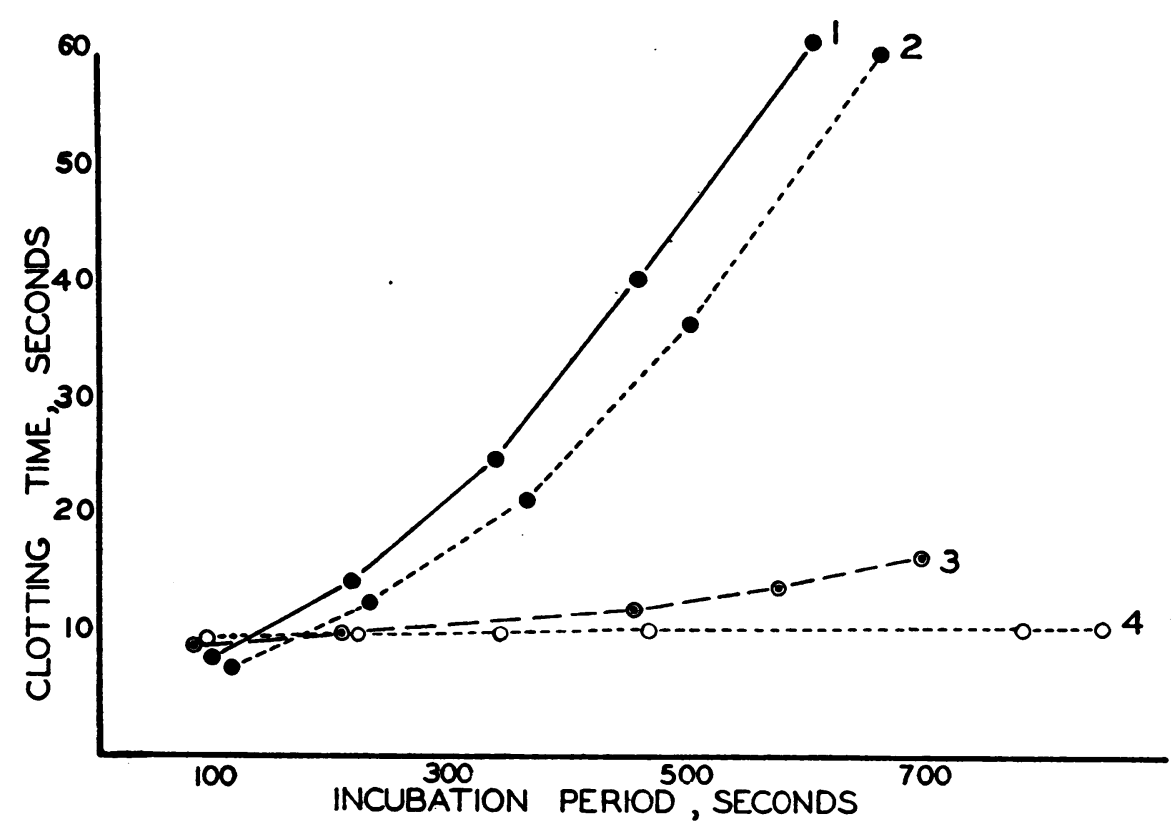

Fig. 4. Thrombin Inactivation Study, Human Plasma, $37^{\circ} \mathrm{C}$.

1. Normal. 2. Dialyzed. 3. Heated 20 minutes at $60^{\circ} \mathrm{C}$. 4. Heated 20 minutes at $66^{\circ} \mathrm{C}$.

Curve 1. $2.0 \mathrm{cc}$. thrombin solution plus $0.2 \mathrm{cc}$. fresh human plasma, incubated, 0.2 cc. mixture added to $0.4 \mathrm{cc}$. fresh human plasma. Curve 2. Same experiment after dialysis of plasma against 0.9 per cent $\mathrm{NaCl}$ solution, using undialyzed plasma in test for residual thrombin. Curves 3 and 4. Plasma heated, filtered and tested as in Curve 1. using unheated plasma in test for residual thrombin.

urement of residual thrombin in these experiments was made with fresh human plasma.

The experiments of Figure 6 indicate that the solution of the horse serum protein fraction soluble at $2.00 \mathrm{M}$. $\left(\mathrm{NH}_{4}\right)_{2} \mathrm{SO}_{4}$ and precipitated at saturation possesses greater power to inactivate thrombin than does serum itself. The protein fraction was dissolved in 0.9 per cent $\mathrm{NaCl}$ solution and, since the protein content was 0.0694 gram per cc. as compared with 0.0650 gram per cc. for the serum itself, the inactivating property has obviously undergone concentration. The protein precipitated at $2.00 \mathrm{M}$. $\left(\mathrm{NH}_{4}\right)_{2} \mathrm{SO}_{4}$ and taken up in 0.9 per cent $\mathrm{NaCl}$ solution to make 0.0786 gram of protein per cc. has little antithrombic power. The fractionation of serum protein for these experiments was done at $4^{\circ} \mathrm{C}$., using the technique of T. L. McMeekin (5).

In other experiments it was found that a hemocuprein solution containing 0.0220 gram of protein per cc. showed no inactivating power against the standard thrombin solution when tested as de- scribed above. A solution of horse serum crystalbumin also was found to be without inactivating power. The question of the possible importance of inorganic constituents of serum in the inactivation phenomenon was also studied. Horse serum was ashed with sulfuric acid, the residue was taken up in a volume of distilled water equal to that of the original serum, and the $\mathrm{pH}$ was adjusted to 7.4. The resultant clear solution had no power to inactivate thrombin, from which one may conclude that the antithrombic activity of serum does not reside in its inorganic components.

In what manner vitamin $\mathrm{K}$-active substances, such as 2-methyl-1,4-naphthoquinone, condition the formation of prothrombin in the body has not yet been determined, but it is possible that such substances supply a prosthetic group for the globulin molecule. The possible relationship of vita$\min \mathrm{K}$ to the thrombin-inactivation phenomenon under study was investigated as follows: Two cc. of the standard thrombin solution were inactivated by incubation with $0.2 \mathrm{cc}$. horse serum for 
10 minutes at $37^{\circ} \mathrm{C}$. Then $0.4 \mathrm{mgm}$. of a highly $\mathrm{K}$-active water-soluble sodium bisulfite derivative of 2-methyl-1,4-naphthoquinone (probably the sodium salt of the 3-sulfonic acid addition product) was added. No restoration of thrombic potency occurred on incubating the solution at $37^{\circ}$ C. Addition of the vitamin $\mathrm{K}$ substance to the thrombin solution before the serum was added did not affect the rate of inactivation of the thrombin.

\section{DISCUSSION}

The lack of species specificity in the interaction of the different mammalian clotting factors studied in these experiments is clear. There may be quantitative differences in horse, beef, and human plasma with respect to these factors, but the present study is confirmatory of the usual view that the reaction between thrombin and fibrinogen from various mammalian sources is essentially the same. It is apparent also that the inactivating power of plasma protein is exerted against thrombin from plasma of another species.

Evidently the inactivation of thrombin does not depend on conditions set up by the conversion of fibrinogen to fibrin, for the precipitation of purified fibrinogen by thrombin is not followed by progressive reduction in potency of the residual thrombin. Rapid inactivation results if preserved horse serum is added to thrombin, as shown in the present study. It is not surprising, then, to find that immediate removal of the clot after addition of plasma to thrombin has no effect on the rate of inactivation of thrombin.

As shown above, the inactivation of thrombin by plasma proceeds exponentially. In studying plasma from the same normal human subjects repeatedly over a period of time, the inactivation rate is remarkably constant. The agreement between plasma samples from different normal individuals is close. These findings led to a study of the inactivating property in plasma from patients

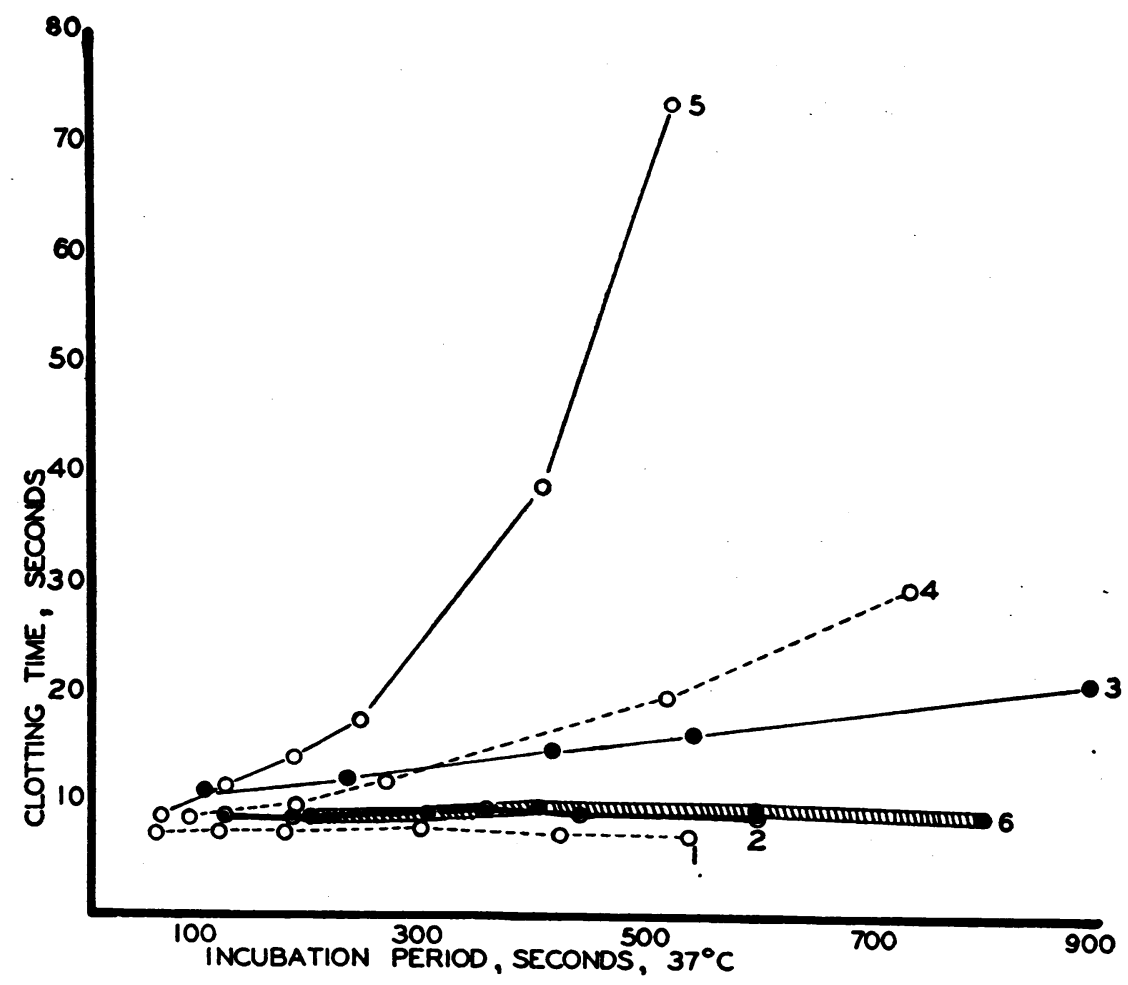

Fig. 5. Thrombin Inactivation Study, Horse Serum Protein Fractions

Curve 1. $2.0 \mathrm{cc}$. thrombin solution plus $0.2 \mathrm{cc}$. solution of protein fraction, incubated, $0.2 \mathrm{cc}$. mixture added to $0.4 \mathrm{cc}$. fresh human plasma. Curves $2,3,4,5$, and 6 similarly obtained with corresponding protein fractions, as shown in Table I. 


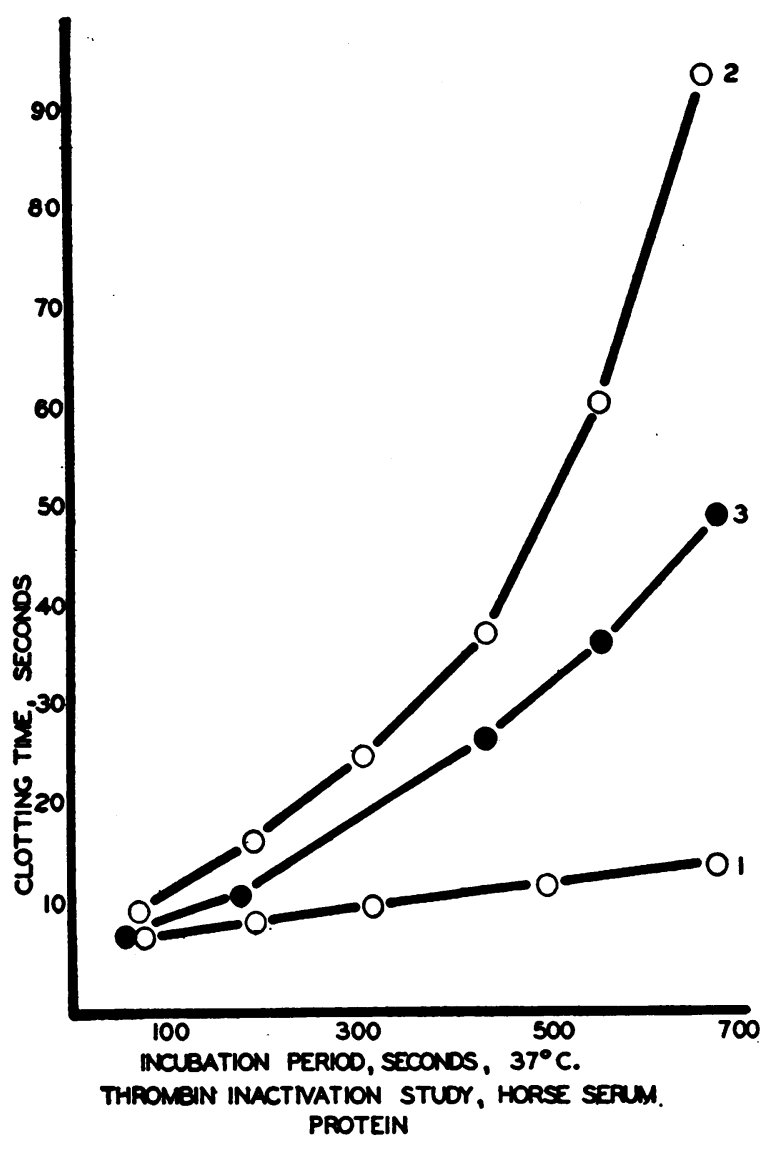

Fic. 6. Thrombin Inactivation Study, Horse Serum Protein

Curve 1. $2.0 \mathrm{cc}$. thrombin solution plus $0.2 \mathrm{cc}$. solution horse serum protein fraction (fraction precipitated at 2.0 M. $\left(\mathrm{NH}_{4}\right)_{2} \mathrm{SO}_{4}$, and dissolved in 0.9 per cent $\mathrm{NaCl}$ solution to yield 0.0786 gram of protein per cc.). Mixture incubated, and $0.2 \mathrm{cc}$. mixture added to $0.4 \mathrm{cc}$. fresh human plasma. Curves 2 and 3 similarly constructed, Curve 2 with solution of horse serum protein fraction soluble at $2.0 \mathrm{M}$. $\left(\mathrm{NH}_{4}\right)_{2} \mathrm{SO}_{4}$ but precipitated at saturation and containing $\mathbf{0 . 0 6 9 4}$ gram of protein per cc. in 0.9 per cent $\mathrm{NaCl}$ solution, Curve 3 with untreated horse serum containing 0.0650 gram of protein per $c c$.

with various diseases, the results of which are to be reported.

From the data shown in Figure 4 it can be seen that the power of inactivating thrombin is not lost when plasma is dialyzed against 0.9 per cent $\mathrm{NaCl}$ solution. This fact, together with the demonstrable heat lability of this property in plasma, makes it clear that thrombin inactivation is a function of the plasma proteins. The studies on serum protein fractions shown in Figures 5 and 6 indicate a localization of the antithrombic property not merely in the albumin fraction, but in a particular part of the albumin fraction. By far the most active fraction studied was that precipitated at $2.80 \mathrm{M}$. $\left(\mathrm{NH}_{4}\right)_{2} \mathrm{SO}_{4}$.

It is of interest that a fraction of horse serum protein can be salted out which yields a solution of greater antithrombic power than the serum itself. It is possible that the power to inactivate thrombin is the property of an individual protein constituent of the plasma albumin, and that the reaction is enzymatic in nature.

\section{CONCLUSIONS}

1. Thrombin prepared from beef plasma is rapidly inactivated when incubated with human or beef plasma or horse serum.

2. Thrombin is not inactivated when incubated with fibrinogen solution.

3. Inactivation of thrombin by plasma or serum proceeds exponentially, and plasma samples from different normal individuals or from the same individuals over a period of time yield quantitatively similar results.

4. The property of inactivating thrombin is resident in a particular fraction of plasma albumin which is capable of being concentrated and may be enzymatic in nature.

The authors wish to express their gratitude to Drs. E. J. Cohn and T. L. McMeekin for suggestions in this study.

\section{BIBLIOGRAPHY}

1. Gasser, H. S., The significance of prothrombin and of free and combined thrombin in blood serum. Amer. J. Physiol., 1917, 42, 378.

2. Quick, A. J., The normal antithrombin of the blood and its relation to heparin. Amer. J. Physiol., 1938, 123, 712.

3. Eagle, H. J., Studies in blood coagulation; the rôle of prothrombin and of platelets in the formation of thrombin. J. Gen. Physiol., 1935, 18, 531.

4. Stewart, J. D., and Rourke, G. M., Prothrombin and vitamin $\mathrm{K}$ therapy. New England J. Med., 1939, 221, 403.

5. McMeekin, T. L., Serum albumin. I. The preparation and properties of crystalline horse serum albumin of constant solubility. J. Amer. Chem. Soc., 1939, 61, 2884. 